\title{
超短光パルス測定法
}

\author{
菊池和朗 \\ 東京大学 先端科学技術研究センター（テ153-8904 東京都目黒区駒場4-6-1）
}

\section{Method of Ultrashort Optical Pulse Measurement}

\author{
Kazuro KIKUCHI \\ Research Center for Advanced Science and Technology, University of Tokyo \\ 4-6-1 Komaba, Meguro-ku, Tokyo 153-8904
}

(Received June 28, 1999)

\begin{abstract}
This paper describes the principle of ultra-short optical pulse measurement including novel measuremet methods that have recently been developed. The SHG auto-correlation method is most widely used to estimate the short optical pulse width. However, two-photon absorption in LED's and photodiodes has been applied to generate the nonlinear correlation signal instead of SHG, and has revealed remarkable performance in the short pulse measurement. On the other hand, the cross-correlation method such as the optical sampling method has been introduced into the measurement of transient response of optical devices and the pulse pattern measurement in ultra-high speed optical transmission systems. The reconstruction of the waveform and phase from the measured correlation signal is also an important problem. This paper deals with the FROG (Frequency Resolved Optical Gating) developed for this purpose.
\end{abstract}

Key Words: Ultrashort optical pulse, Auto-correlation, Cross-correlation, SHG, Two-photon absorption

1.はじめに

フェムト秒領域に達する超短光パルスを発生する技術 は,パルス波形や周波数チャープの測定法の開発と一体に なって発展してきた。このような超短光パルスに適用可 能な測定法は非線形相関法に限られるが, 中でもSHG結晶 を用いた強度自己相関法が, 超短光パルス波形の測定に広 く用いられている。この方法では, 測定対象の光パルスに 可変な遅延を加え,2つのパルスの重なりを非線形光学結晶 から発生する二次高調波を用いて測定する。正確なパル ス波形は測定できないが, おおよそのパルス幅を知ること ができる。

これに対して, 近年, フォトダイオードや発光ダイオー ドの二光子吸収過程を用いた自己相関測定法が提案され ている.この方法では, 二光子吸収電流の測定により SHG の測定と同等な情報が得られるため, 従来の非線形光学結 晶を用いた方法に比べて測定系の構成が簡易となる．従 来の非線形光学結晶を用いたシステムでは,結晶の位相整 合条件を満足する必要があり,この条件が測定可能なパル ス幅を制限する。しかし，二光子吸収を用いた場合には，位 相整合条件による制約を受けないので, 極めて広帯域なシ ステムを構築できるという特徴もある。また, 偏波依存性 を持たないことも，二光子吸収を用いた方法の大きな利点 の一つである。
光ファイバ通信システムにおいても, 波長 $1.5 \mu \mathrm{m}$ 帯での ピコ秒〜サブピコ秒領域の超短光パルスを用いた光領域 時間多重システムの研究開発が進んでおり, 超短光パルス 計測システムを開発する必要性が高まっている。これら の応用ではとくに, 比較的低パワーの光パルスを扱うた め, システムの高感度性が要求される。 また, システムの 簡易さ, 操作性, 低価格なども重要な要素であり, この種の 応用には, 二光子吸収を用いた自己相関法は好適な測定法 である。

一方, 光サンプリング法などの相互相関を用いた光パル ス測定法も重要性を増している。相互相関測定を行うに は, 被測定パルスに同期した, 幅が十分に狭いパルスを必 要とするが, 自己相関法とはことなり, 非対称性を含めパ ルス波形を正確に決定することができる．この方法は, 光 デバイスの過渡応答や光ファイバ中での光パルス伝搬特 性の測定に適用されている。

また, 光パルス波形のみならずチャープ特性を測定する ことも重要な課題である。チャープ特性を正確に把握す ることにより,パルス幅を圧縮することが可能となるから である。この目的のために, FROG (Frequency Resolved Optical Gating) と呼ばれる測定法が開発され, 広く用いられつ つある。

本論文では,このような超短光パルス測定法の原理を, 最 近の動向も含めながら解説する. 


\section{SHG 自己相関測定法}

\section{1 測定法の概要}

超高速フォトダイオードによっても検出できないピコ 秒以下の光パルスの波形を知るには, 非線形相関測定を行 う必要がある。この中で, 同一のパルス同士で相関をとる 方法が自己相関法と呼ばれる。非線形自己相関測定には, 二次以上の光学的非線形性を必要とするが,これまで二次 高調波発生 $(\mathrm{SHG})$ が最も一般的に用いられている.

自己相関法では, $2 つ$ の光パルスを時間をずらして重ね合 わせる。この際,遅延時間差は2つのパルスの光路差を光速 で割ったものである，光路差の精度は容易に $1 \mu \mathrm{m}$ 以下にで きるから, $\mathrm{fs}$ の精度を持つ時間軸を作ることができる。こ のような可変時間差は, 通常, Fig.1に示すマイケルソン型 の光学遅延線を用いて実現される.

Fig.1には, 2つのビームの光軸が一致していない非共軸 配置の例を示しているが,ここではまず, $2 つ の$ 光軸が一致 した共軸配置(マイケルソン干渉計)を考えよう。このと き,信号光電界の複素振幅を $E(t)$, キャリア角周波数を $\omega_{0}$ と すると,時間差てを持つ干涉計から出射する光の複素振幅は

$$
e(t)=E(t) \exp \left(-\mathrm{j} \omega_{0} t\right)+E(t-\tau) \exp \left[-\mathrm{j} \omega_{0}(t-\tau)\right]
$$

となる。この光電界をSHG結晶に導き，二次高調波をパル 又幅よりも十分長い時間応答特性をもつ光検出器で測定 する．測定されるSH光強度は

$$
\int_{-\infty}^{+\infty}\left|e(t)^{2}\right|^{2} \mathrm{~d} t
$$

に比例する。この式に(1)を代入すると

$$
\begin{aligned}
S_{2}(\tau)= & +2 G_{2}(\tau)+4 \operatorname{Re}\left[F_{1}(\tau) \exp \left(-\mathrm{j} \omega_{0} \tau\right)\right] \\
& +\operatorname{Re}\left[F_{2}(\tau) \exp \left(-2 \mathrm{j} \omega_{0} \tau\right)\right]
\end{aligned}
$$

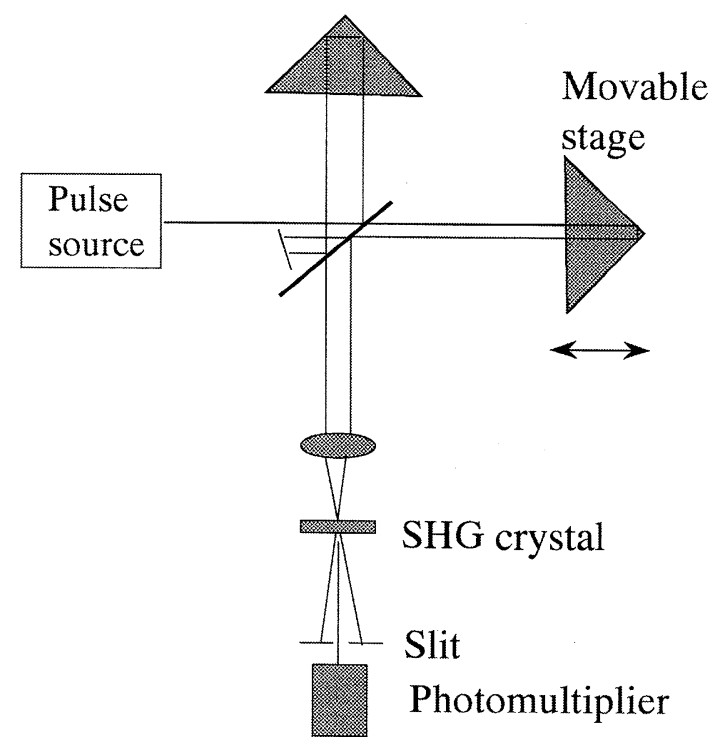

Fig.1 SHG intensity auto-correlator in the non-collinear configuration.
となる。ここで

$$
\begin{aligned}
& G_{2}(\tau)=\left\langle|E(t)|^{2}|E(t-\tau)|^{2}\right\rangle \\
& F_{1}(\tau)=\frac{1}{2}\left\langle\left(|E(t)|^{2}+|E(t-\tau)|^{2}\left|E(t) E^{*}(t-\tau)\right\rangle\right.\right. \\
& F_{2}(\tau)=\left\langle E^{2}(t) E^{*^{2}}(t-\tau)\right\rangle
\end{aligned}
$$

である．ただし光電界は, $G_{2}(0)=1$ となるように規格化し てある。式(3)がフリンジ分解SHG自己相関信号と呼ば れ,マイケルソン干渉計に拀いて, 遅延時間差てを一定速度 で掃引することにより測定できる. 式(3)の第一項は,個々 のパルスが独立に発生するSH光強度であり, 測定の際の バックグランドとなる。第二項 $G_{2}(\tau)$ は, 二次の強度自己相 関関数と呼ばれる．第三項と第四項は,干渉項である.

一方, Fig.1のように2つのビームの光軸を非共軸にして SHG結晶に入射し, 2 つのビームの重なりから生じるSH光 のみを検出することも可能である。この場合には共軸配 置の場合とは異なり,式(3)においてバックグランドや干渉 項が除去され, $G_{2}(\tau)$ のみが直接測定される.

SH光強度は通常微弱であるので, 高い感度を有する光電 子増倍管を用いて検出することが多い。また光ファイバ 通信などで使用する光パルスは, ピークパワーが低いの で,ささらに検出感度をあげるために光子計数受信器を用い ることもある。

\section{2 パルス波形, チャープの測定}

Fig.1に示す非共軸配置のSHG自己相関測定により $G_{2}(\tau)$ が測定されると,これを用いてパルス波形を推定すること ができる．SH光強度は2つのパルスの強度の積に比例する から,パルスの重なりが大きいときに大きな $\mathrm{SH}$ 光強度が得 られ,パルスが重ならないときにはSH光が生じない.した がって $G_{2}(\tau)$ の半值幅とパルス幅は, 比例関係にあることが 推察される. しかし,この比例定数を求めるにはパルス波 形をあらかじめ仮定する必要がある。パルス波形を仮定 すれば, 強度自己相関波形 $G_{2}(\tau)$ の半值幅 $\Delta \tau$ と実際のパル 又幅 $t_{p}$ の比が決定できる. Table 1に, 種々の仮定された波 形に対する $\Delta \tau / t_{p}$ を示す。しかし実際には, 被測定光パルス の波形は未知であることが多く,被測定パルスが非対称で ある場合もある。このような場合, $G_{2}(\tau)$ によるパルス波形 の評価は,厳密なものではなくパルス幅の目安を与える程 度の意味を持つ。

一方, 共軸配置の自己相関測定により得られるフリンジ 分解自己相関信号 (3) は. $G_{2}(\tau)$ 以外に干渉項を含むのでよ り情報量が多い. 干渉項のうち, $F_{2}(\tau)$ がパルスの評価のた

Table 1 Relation between the actual pulse width and the FWHM (full width at half maximum) of the autocorrelation trace for various intensity waveforms.

\begin{tabular}{cc}
\hline \hline Intensity waveform & $\Delta \tau / t_{p}$ \\
\hline Rectangular & 1 \\
Gaussian & 1.41 \\
sech $^{2}$ & 1.55 \\
Lorenzian & 2 \\
\hline \hline
\end{tabular}


めに重要である。長沼らは,フリンジ分解SHG自己相関信 号から抽出される $G_{2}(\tau)$ および $F_{2}(\tau)$, さらに電界に対する 自己相関関数 $G_{1}(\tau)=\left\langle E(t) E^{*}(t-\tau)\right\rangle$ を用いれば, 非対称パ ルスを含む任意のパルス波形㧍よび位相を時間軸方向の 不確定性を除いて完全再生できることを証明し，干渉相関 繰り返し計算法と呼ばれる再生のためのアルゴリズムを示 した1). また対称パルスに限定すれば, $G_{2}(\tau)$ および $\left|F_{2}(\tau)\right|$ のみから完全再生が可能となる。この種の再生問題は, 一 般的には“一次元位相再生問題”として知られている.

式(3)より，てを等速で掃引したとき,フリンジ分解SHG自 己相関信号はDC成分, $\omega_{0}$ 成分, $2 \omega_{0}$ 成分の 3 つのスペクトル 成分からなることがわかる。このため $G_{2}(\tau)$ および $\left|F_{2}(\tau)\right|$ は,フリンジ分解SHG自己相関信号からフィル夕を用いて 容易に抽出できる。このうちDC成分である $G_{2}(\tau)$ は, 低域 フィルタにより分離できる。高域フィルタを用いれば $2 \omega_{0}$ 成分である $\operatorname{Re}\left[F_{2}(\tau) \exp \left(-2 \mathrm{j} \omega_{0} \tau\right)\right]$ が分離され，これを包絡 線検波することにより $\left|F_{2}(\tau)\right|$ が求まる.

すでに述べたように対称パルスに関しては,このように して抽出された $G_{2}(\tau)$ 拉よび $\left|F_{2}(\tau)\right|$ から, 繰り返し計算によ りパルス波形と位相を完全再生できる。しかしょり簡便 には, $G_{2}(\tau)$ と $\left|F_{2}(\tau)\right|$ の比較により,チャープと呼ばれる位 相の時間変化の大雑把な評価を行うこともできる2).

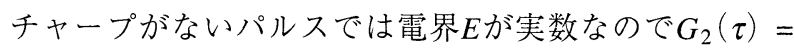
$\left|F_{2}(\tau)\right|$ であるが,チャープを持つパルスでは $\left|F_{2}(\tau)\right|$ の半值幅 は $G_{2}(\tau)$ の半值幅より必ず狭くなる。これらの半值幅の比 により,チャープパラメータの扮拧よその大きさを推定す ることができる(3.2節参照).

\section{3. 二光子吸収を用いた自己相関測定}

\section{1 二光子吸収と $\mathrm{SHG}$ の比較}

前章ではSH光強度の測定により, 二次の自己相関が得ら れることを示した。これは, SH光電界が $e(t)^{2}$ に比例し, $\mathrm{SH}$ 光強度が $\int_{-\infty}^{+\infty}\left|e(t)^{2}\right|^{2} \mathrm{~d} t$ に比例することに起因する。この 式は,

$$
\int_{-\infty}^{+\infty}\left\{\left|e(t)^{2}\right|^{2}\right\} \mathrm{d} t
$$

と表すこともできる. $|e(t)|^{2}$ は基本波の光子数に比例する から,基本波光子数の 2 乗に比例して二次高調波光子が生成 されることを示している。

次に半導体中の二光子吸収過程について考えよう。半 導体にバンドギャップエネルギー $E_{g}$ より大きなエネルギー $\left(\hbar \omega>E_{g}\right)$ を持つ光子が入力すると, 光子の吸収が拀き, 電 子・正孔対が生成される。一方, $E_{g}>\hbar \omega>E_{g} / 2$ のときに は, 二光子吸収が㧍きる。 すなわち, 2 個の光子エネルギー により,はじめてバンドギャップをこえるエネルギーが得 られる。したがって, 二光子吸収によって生じる光電流は 入射光子数の 2 乗に比例し, その大きさは二次高調波強度を 表す式(7)と同一である.

SHGでは, 基本波光子 2 個で二次高調波光子 1 個が生成さ れ, これが光検出器で電子・正孔対に変換され, 光電流が
測定される. 二光子吸収では, 光子 2 個で直接, 電子. 正孔 対が作られ,これが光電流となる。したがってどちらの場 合でも, 同じ自己相関信号が得られることは明らかであ る.

二光子吸収電流は, フォトダイオードやLEDなどを用い て検出可能である。この方法を用いると, 従来のSHG結晶 と高感度光検出器がフォトダイオードやLEDに置換できる ため, システム構成が大幅に簡略化できる。近年, GaAsP フォトダイオード3)掠よびAlGaAs LED ${ }^{4)}$ 用いた800nm帯 でのフェムト秒パルスの測定が報告がなされている。ま た, 波長 $1.5 \mu \mathrm{m}$ 帯では, $\mathrm{Si}$ フォトダイオード5)拈よびSi-APD ${ }^{6}$ を用いた報告がある。

これらの方式は, 入射光の偏波に検出感度が依存しない という特徵がある。また, SHG結晶を用いた場合には, SH 光の高効率発生のために結晶の位相整合条件を満足させ ねばならず,この条件が測定可能なパルス幅を制限してい た。しかし二光子吸収を用いた方法では,このような条件 が課せられないので本質的に広帯域となり,フェムト秒パ ルスでも容易に測定可能となる。

また, 導波路構造を用いて二光子吸収の相互作用長を長 くすれば,検出感度をあげることができる。このような試 みとしては, AlGaAs導波路を用いた1.06 $\mathrm{mm}$ 帯パルス測定の 報告7,8), InGaAsP導波路を用いた $1.5 \mu \mathrm{m}$ 帯光パルス測定の報 告9) $1.3 \mu \mathrm{m}$ 帯半導体レーザーを用いた $1.5 \mu \mathrm{m}$ 帯光パルスの 報告10)がある。しかしこれらの方法では, 偏波依存性や導 波路の分散による測定限界などが問題点となり得る.

SHG強度自己相関法では, 非共軸配置をとることにより 干渉項やバックグランドが除去可能であり, $G_{2}$ のみを直接 測定できる。これに対して二光子吸収を用いた自己相関 法では, 非共軸配置をとったとしても個々のパルスが独立 に発生する二光子吸収信号を除去できないので, 常にバッ クグランドが存在する。このため,二光子吸収を用いた強 度自己相関測定では非共軸配置をとるメリットがなく,多 くの場合共軸配置が用いられる。

3.2 Si-APDに扔ける二光子吸収を用いた高感度自己相 関測定器

本節では,筆者が研究しているSi-APDにおける二光子吸 収在用いた光パルス相関測定法について説明する6)。SiAPDを二光子吸収体に用いると, 二光子吸収光電流はなだ れ増倍されるために, 導波路構造を用いることなく検出感 度を極めて向上させることができる，従来のSHG結晶と 光電子増倍管の機能は, APD1個で実現され, システム構成 が簡易化される。

$\mathrm{Si}-\mathrm{APD}$ に波長 $1.55 \mu \mathrm{m}$ のCW光を入射した時の二光子吸

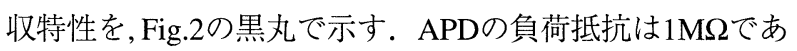
り, 低雑音演算増幅器により出力電圧は20dB増幅される. APDの電流増倍率は100に設定している。 Fig.2の実線は $V[\mathrm{mV}]=13.0+22.7 P[\mathrm{~mW}]+1.82 P^{2}\left[\mathrm{~mW}^{2}\right]$ と表される. 第 1 項は背景光, 第2項は線形吸収, 第 3 項は二光子吸収の寄与 を示す。

Fig.3に自己相関光パルス測定器の構成を示す. マイケ ルソン干渉計の出力が, Si-APDからなる二光子吸収光受信 


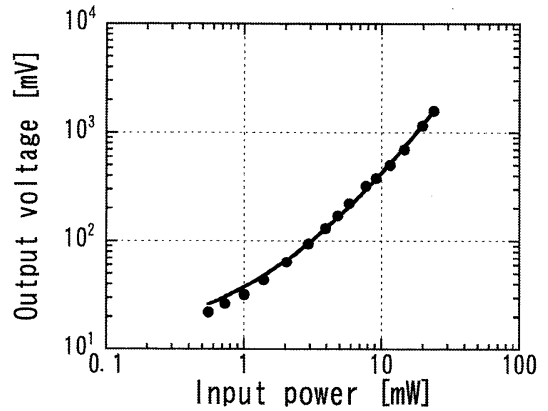

Fig.2 Two-photon absorption characteristics of a Si APD. The output voltage of the APD receiver is measured as a function of the input $\mathrm{CW}$ power at $1.55 \mu \mathrm{m}$. The solid curve shows a theoretical fit.

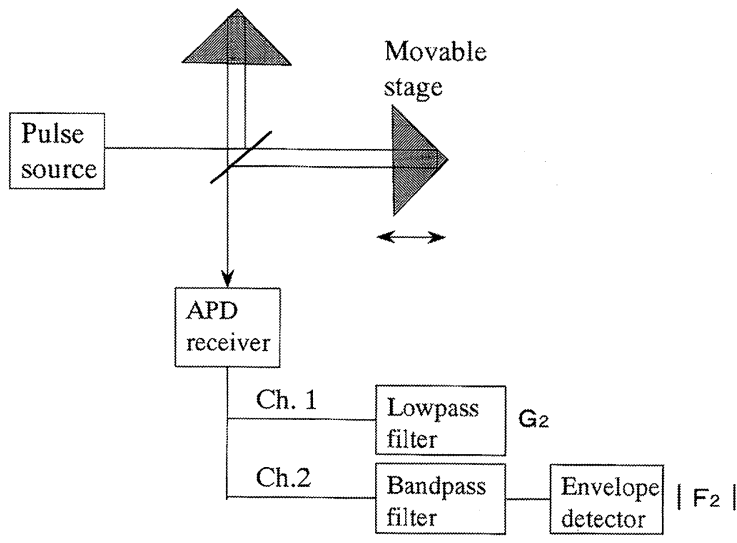

Fig.3 Experimental setup for the interferometric autocorrelator using a Si APD. It consists of the Michelson interferometer, the APD receiver, and the signal-processing circuit.

器に導かれる．フリンジ分解自己相関信号を与えるAPD 受信器の出力の一方 (Ch.1) は, 低域フィル夕に導かれる. このチャンネルからは強度自己相関関数 $G_{2}(\tau)$ が出力され る.一方,他方のチャンネル (Ch.2)では, APD受信器の出力 はフリンジ周波数の2倍の中心周波数を持つ帯域フィル夕 でろ波された後,包絡線検波される。このチャンネルの出 力は $\left|F_{2}(\tau)\right|$ である。

上記の装置を用いて測定された, $1.5 \mu \mathrm{m}$ 帯光パルスの $G_{2}(\tau),\left|F_{2}(\tau)\right|$ の例をFig.4に示す．強度自己相関幅は半值全 幅で0.31psであり, sech 型パルス波形を仮定するとパルス 幅200fsとなる．実線と破線がほぼ一致していることか ら,このパルスにはチャープがほとんどないことがわか る.

この装置では, APDの増倍率をあげることにより, 測定 感度を向上させることができる．自己相関測定系の感度 は, 平均パワーとピークパワーの積で表される。本装置の 測定感度限界は, $2 \mathrm{~mW}^{2}$ 以下であり, 光電子増倍管を用いた SHG自己相関測定装置に匹敵する感度を達成している。

\section{4. 相互相関測定法}

自己相関測定法は, 未知の光パルス波形を知るための強

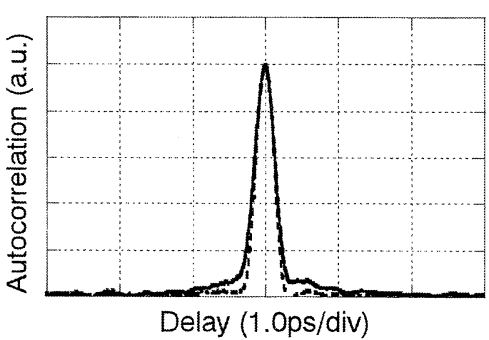

Fig.4 Intensity auto-correlation trace of $1.5-\mu \mathrm{m}$ optical pulses measured by two-photon absorption in a $\mathrm{Si}$ APD. The broken curve shows $\left|F_{2}(\tau)\right|$. Since $\left|F_{2}(\tau)\right|$ is in good agreement with $G_{2}(\tau)$, we find that the pulses are almost chirp-free.

力な方法である。しかし, 光デバイスの過渡応答特性の評 価や光ファイバ中を伝送した光パルス波形の評価などに は,相互相関測定を用いたい場合も多い。特に最近, 光ファ イバレーザーや半導体レーザーを用いた能動モード同期 レーザー技術が進歩し, 時間ジッタの小さい超短パルス列 の発生が可能になってきた。これに伴い，モード同期レー ザーを用いた相互相関測定の重要性が高まっている。

Fig.5は, 相互相関を用いた光ファイバの伝送波形の測定 系である ${ }^{11)}$ 。外部共振器型モード同期半導体レーザーか ら生成される中心波長1553nm, パルス幅1.7ps繰り返し周波 数10GHzの光パルスを, 被測定用とサンプリング用に二つ に分岐する。サンプリング用光パルスに対しては, 相互相 関測定の時間分解能を上げるために, 0.2psまで非線形圧縮 を行っている. 可変遅延を加えた後このサンプリング用 光パルスと被測定光パルスを合波し,両者はSi-APDからな る二光子吸収光受信器に導かれる。電気信号に変換され た信号は低域濾過され, オシロスコープに相互相関波形が 直接表示される。相互相関測定器の時間分解能は, サンプ リングパルスのパルス幅とジッタの和で決定され, 本測定 器では約 $0.3 \mathrm{ps}$ となる。

この装置を用いて, 零分散波長1553nmの光ファイバ中を 80km伝送した後の光パルス波形が測定されている. Fig.6 にその相互相関波形を示す。光パルスの波長がほぼ光 ファイバの零分散波長に一致しているので, 分散スロープ の影響を受けて光パルスは非対称になり,光パルスの後端 にエネルギーがシフトしていることが明確に測定されて いる.

この実験のように, 繰り返し周波数が高い能動モード同 期レーザーパルスを用いる場合には, 出力パルスと相関を とるサンプリングパルスが, 同一のパルスである必要はな い. 能動モード同期レーザーパルス列の時間ジッタは十 分に抑圧されており,パルス間隔も短いので, 何周期も離 れたパルスの間で相互相関をとることが可能である。こ のため, ファイバのような大きな時間遅延を伴う素子の評 価を行うことができる.

また, 被測定パルス列からクロック抽出回路を用いて,ク ロック信号を抽出し，これを用いて被測定レーザーに同期 したサンプリングパルス列を発生させることもできる. このサンプリングパルス列と被測定パルス列の相互相関 を, SHGや二光子吸収を用いて測定すればよい。これはサ 


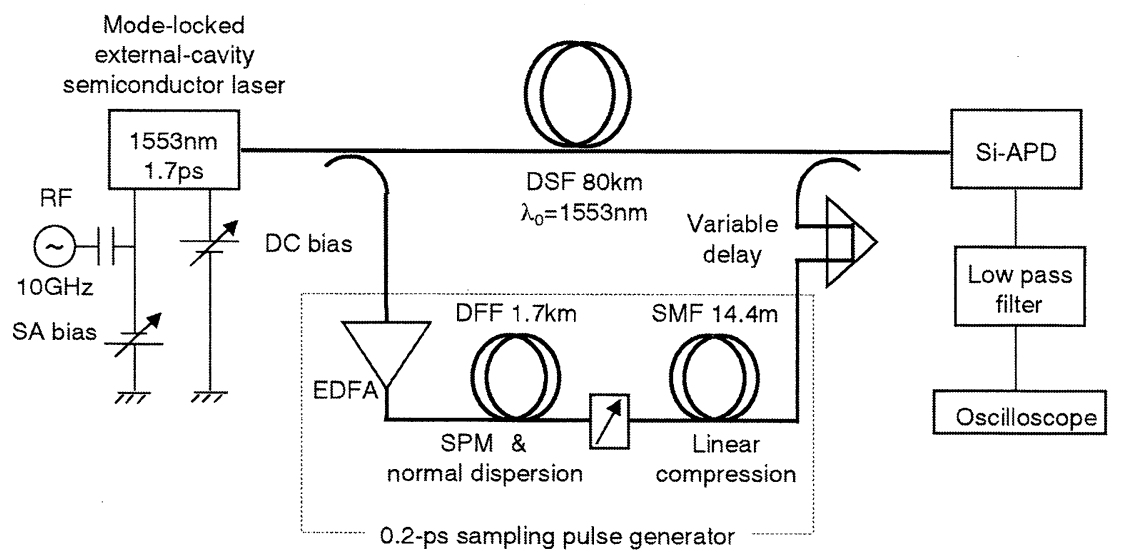

Fig.5 Experimental setup of the cross-correlator for the measurement of picosecond-pulse transmission characteristics.

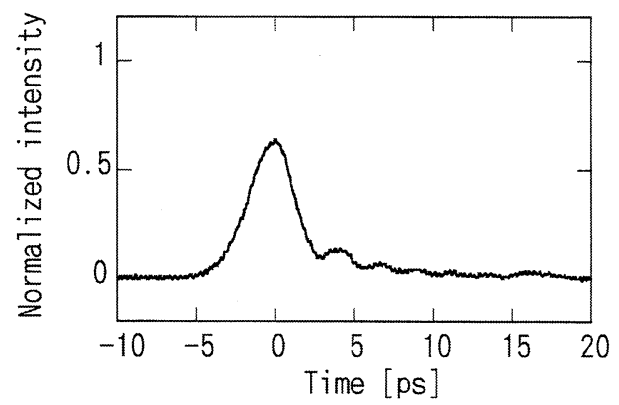

Fig.6 Cross-correlation trace of the pulse transmitted through a $80-\mathrm{km}$-long dispersion-shifted fiber.

ンプリングオシロスコープの原理を光測定に適用したも ので, 光サンプリング法と呼ばれる.

これらの方法でパルス波形が測定できれば,被測定パル スのスペクトルもしくは電界自己相関関数 $G_{1}(\tau)$ を用いた 繰り返し計算により,位相を再生することができる12)。こ れも一次元位相再生問題の一種である.

\section{5. 短時間フーリエ変換によるパルス解析法}

チャープをともなう信号の解析法として, 短時間フーリ エ変換という手法が知られている13). 信号に時間ゲート をかけ, 各時刻ごとのスペクトルを求める方法である。こ の手法に基づき,FROG (Frequency Resolved Optical Gating) と呼ぶ自己相関光パルス解析法が開発され,広く用いられ つつある14).

信号 $s(\tau)$ に対して時間空 $h(\tau-t)$ をかける。

$$
s_{t}(\tau)=s(\tau) h(\tau-t)
$$

信号と時間空の相対的な時間差 $t$ を可変とする. 式 $(8)$ を フーリエ変換すると時間ゲートされた信号のスペクトル

$$
S_{t}(\omega)=\frac{1}{\sqrt{2 \pi}} \int \exp (-\mathrm{j} \omega \tau) s(\tau) h(\tau-t) \mathrm{d} \tau
$$

が得られる. $\left|S_{t}(\omega)\right|^{2}$ は短時間フーリ工変換(あるいはスペ クトログラム)と呼ばれる。これを用いれば,スペクトルの 時間変化を表示できるので,パルスの性質を直感的に把握
できる。

光パルス測定に短時間フーリエ変換を適用するには, SHGを用いた相互相関測定系で, 各時間差ごとにSH光のス

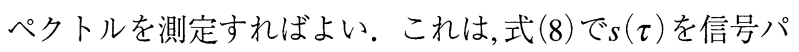
ルス電界, $h(\tau-t)$ をゲートパルス電界とすれば, $s_{t}(\tau)$ がSH 光電界をあらわすことから明らかであろう。このとき ゲートパルス電界が既知であれば, 短時間フーリエ变換か ら信号を完全再生する公式が存在する13).

これに対して,ゲート信号 $h$ として自分自身の電界を用い るのがSHG-FROGと呼ばれる測定法である。すなわち

$$
s_{t}(\tau)=s(\tau) s(\tau-t)
$$

である。この測定は, 非共軸のSHG自己相関測定系 (Fig.7) において, SH光のスペクトルを測定することにより簡単に 実現できる。この場合には,ゲート信号が既知である場合 のような直接的な再生公式は存在しないが, 繰り返し計算 により短時間フーリエ変換から信号を再生するアルゴリ ズムが発見されている。

このようなアルゴリズムでは, $\omega, \tau$ を変数とする二次元 データから信号を再生する。この手法は,一般に“二次元位 相再生問題”と呼ばれる。これに対して第2章で述べたフ リンジ分解SHG自己相関信号からの信号再生や, 第4章で述 べた相互相関により測定された信号波形と信号スペクト ルからの信号再生は“一次元位相再生問題”に属する. 二次 元位相再生法の方が,一次元位相再生法よりも解の収束性 が遥かに優れていることが知られている。このため, 測定 法の簡便さと相俟って, SHG-FROGは標準的な超短光パル ス測定法としての地位を確立しつつある。

一方, 二光子吸収を用いた相関測定法は, SHGとは異な り相関信号のスペクトルを測定できないので, FROGを構 成することはできないという久点がある.

\section{6. むすび}

非線形自己相関, 相互相関に基づく超短光パルス測定法 について解説した。

現在超短光パルス技術は, 超高速現象の観測から超高速 
光ファイバ通信まで,広く応用されているが,これを支え るのが超短パルス計測技術である。今後, 超短光パルス発 生技術と測定技術が両輪となって,さらに新しい応用分野 が開拓されることを期待したい。

\section{参考文献}

1) N. Naganuma, K. Mogi, and H. Yamada: IEEE J. Quantum Electron. 25 (1989) 1225.

2) K. Mogi, K. Naganuma, and H. Yamada: Jpn. J. Appl. Phys. 27 (1988) 2078.

3) J. K. Ranka, A. L. Gaeta, A. Baltuska, M. S. Pshenichnikov, and D. A. Wiersma: Opt. Lett. 22 (1997) 1344.

4) D. T. Reid, M. Padgett, C. McGowan, W. E. Sleat, and W. Sibbett: Opt. Lett. 22 (1997) 233.
5) J. M. Dudley, L. P. Barry, P. G. Bollond, J. D. Harvey,and R. Leonhard: Optical Fiber Communication Conference,vol. 6 of 1997 OSA Technical Digest Series, paper ThL4.

6) K. Kikuchi: Electron. Lett. 34 (1998) 123.

7) M. M. Karkhanehchi, C. J. Hamilton, and J. H. Marsh: IEEE Photonics Technol. Lett. 9 (1997) 645.

8) F. R. Laughton, J. H. Marsh, D. A. Barrow, and E. L. Portnoi: IEEE J. Quantum Electron. 30 (1994) 838.

9) H. K. Tsang, L. Y. Chan, J. B. D. Soole, H. P. LeBlanc, M. A. Koza, and R. Bhat: Electron. Lett. 31 (1995) 1773.

10) L. P. Barry, B. C. Thomsen, J. M. Dudley, and J. D. Harvey: Electron. Lett. 34 (1998) 358.

11) K. Kikuchi, F. Futami, and K. Katoh: Electron. Lett. 34 (1998) 2161.

12) R. W. Gerchberg and W. O. Saxton: Optik 35 (1972) 237.

13) L. Cohen: Time-Frequency Analysis (1995) Prentice Hall.

14) R. Trebino, K. W. Delong, D. N. Fittinghoff, J. N. Sweetser, M. A. Krumbügel, B. A. Richman, and D. J. Kane: Rev. Sci. Instrum. 68 (1997) 3277.
超短光パルス測定 (ultrashort optical pulse measurement)

フェムト秒領域に達する超短光パルスを発生する技術 が近年急速に発展している．超高速フォトダイオードに よっても検出できないピコ秒以下の光パルスの波形を知 るには, 非線形相関測定を行う必要がある。中でも, SHG 結晶を用いた強度自己相関法が, パルス波形の測定に広く 用いられている。この方法では, 測定対象の光パルスに可 变な遅延を加えたのち, 光パル入を非線形光学結晶に入射 する．遅延を変化させながら,非線形光学結晶から発生す

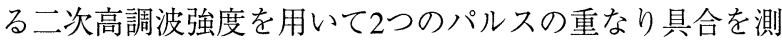
定することによって,抒よそのパルス幅を知ることがで きる.

また,正確なパルス波形掞よび周波数チャープを完全再 生できる非線形相関測定法も重要であり,これまで数多く の研究がなされている．近年この目的のためにFROG (Frequency Resolved Optical Gating) と呼ばれる優れた測定 法が開発され,広く用いられつつある。

(菊池和朗) 